\title{
ROZWÓJ OBSZARÓW METROPOLITALNYCH W ŚWIETLE TRANSFORMACJI SAMORZĄDU TERYTORIALNEGO W POLSCE W LATACH 1990-2014
}

\section{WSTĘP}

Transformacja, jaka nastapiła $\mathrm{w}$ zakresie ustroju oraz $\mathrm{w}$ każdym $\mathrm{z}$ wymiarów życia społeczno-gospodarczego w Polsce po 1989 r., stanowi efekt różnorodnych działań na przestrzeni 25 lat, wynikających z zachodzących procesów konwergencji organizacji i funkcjonowania otoczenia wewnętrznego i zewnętrznego kraju do warunków państw wysoko rozwiniętych Europy Zachodniej, w szczególności zrzeszonych w Unii Europejskiej. W rezultacie przywrócenia demokracji oraz wprowadzenia swobody gospodarczej nastapiło otwarcie się Polski na rynki zagraniczne, to z kolei doprowadziło do: transferu kapitału, informacji i wiedzy (wewnętrzny i zewnętrzny), restrukturyzacji gospodarki, postępu techniczno-technologicznego, a więc rzeczywistej przemiany cywilizacyjnej. Aspiracja do osiagnięcia poziomu jakości życia krajów wysoko rozwiniętych oraz włączenie Polski w obszar ogólnoświatowej aktywności państw zarówno w sektorze publicznym, jak i prywatnym spowodowały implikacje bezpośrednich lub pośrednich procesów w kraju, których źródło i miejsce występowania nie obejmowały działalności podmiotów wyłącznie w granicach jego terytorium (efekt globalizacji). Jednym z takich procesów była narastająca urbanizacja przede wszystkim w zakresie dużych ośrodków miejskich, która wskutek dalszych przemian społeczno-gospodarczych uległa przeformułowaniu w proces metropolizacji.

Postępujący proces metropolizacji jest rozpatrywany w kategorii jednego z istotnych gospodarczych czynników rozwoju, co wielokrotnie podkreślano w raportach organizacji oraz instytucji krajowych i międzynarodowych (opracowania np. OECD czy Unii Europejskiej). Intensyfikacja procesu rozwoju obszarów metropolitalnych stanowi również przedmiot rozważań w ramach polskich dokumentów strategicznych, tj. Koncepcji Przestrzennego Zagospodarowania Kraju 2030, w której odwołano się do Długookresowej Strategii Rozwoju Kraju Polska 2030 i Strategii Rozwoju Kraju 2020. Problematyka zarządzania obszarami metropolitalnymi (ze względu na narastające znaczenie: ekonomiczne, naukowe czy kulturalne silnie zurbanizowanych ośrodków miejskich) jest ważnym wyzwaniem w kontekście długookresowego rozwoju kraju ${ }^{1}$.

${ }^{1}$ Biała księga obszarów metropolitalnych, Ministerstwo Administracji i Cyfryzacji, Warszawa 2013, s. 3. 
U podstaw zainteresowania się autora tematyką obszarów metropolitalnych zarówno w ujęciu delimitacji źródła ich tworzenia, jak i prawno-organizacyjnych form funkcjonowania są narastające procesy kształtowania się tych instytucji w przestrzeni Polski, w szczególności w ostatnich 10 latach, oraz potęgujące się znaczenie przedmiotowych ośrodków w otoczeniu społeczno-gospodarczym kraju i Europy. Podjęcie rozważań w zakresie obszarów metropolitalnych na tle transformacji ustroju i przemian społeczno-gospodarczych, jakie miały i mają miejsce Polsce od 1989 r., wynika również z delimitacji i organizacji tych obszarów w szczególności w efekcie procesów społeczno-gospodarczych, odmiennie od uwarunkowań prawno-instytucjonalnych. Reorientacja podejścia do zarządzania w sektorze publicznym oznacza odstapienie od koncentracji na suwerennej jednostce i dywersyfikację zadań wśród podmiotów różnych szczebli ustroju (administracja rządowa i samorządowa) oraz konkurowanie między sektorami (prywatnym, publicznym i non profit), aby osiagnaćć optymalizację działalności organizacji w kształtowaniu synergii sieci oddziałujaccych wzajemnie na siebie i wpływających na rozwój obszaru instytucji zlokalizowanych w granicach określonego terytorium (poziomy: lokalny, regionalny, ponadregionalny).

Celem artykułu jest przedstawienie zarysu rezultatów transformacji ustroju oraz czynników stanowiacych impulsy do rozwoju społeczno-gospodarczego Polski po 1989 r., istotnych z punktu widzenia postępującego procesu metropolizacji. W ramach artykułu została podjęta również problematyka związana z kształtowaniem się koncepcji i form instytucjonalnych tworzenia obszarów metropolitalnych w kategoriach podmiotów uczestniczących $\mathrm{w}$ funkcjonowaniu sektora publicznego, w szczególności jednostek samorządu terytorialnego, wspomagających zarządzanie na polu optymalizacji świadczenia usług i dostarczania produktów użyteczności publicznej. W rozważaniach skoncentrowano się również na analizie ex post wyznaczonych, z wykorzystaniem polskiej statystyki (GUS), obszarów metropolitalnych oraz zagadnieniach obejmujacych formułowanie podstawowych determinant ich rozwoju, jakie zostały uwzględnione $\mathrm{w}$ dokumentach strategicznych opracowanych na podstawie polityki rozwoju kraju (w szczególności do 2020 r.). W artykule zostały również przedstawione najważniejsze czynniki, które będą miały wpływ na wzmacnianie pozycji obszarów metropolitalnych w nowej perspektywie finansowej ze środków budżetu Unii Europejskiej w latach 2014-2020.

\section{TRANSFORMACJA USTROJU ORAZ WARUNKÓW SPOŁECZNO-GOSPODARCZYCH FUNKCJONOWANIA SAMORZĄDU TERYTORIALNEGO W POLSCE W LATACH 1990-2014}

Transformacja ustrojowa zainicjowana w Polsce na przełomie lat osiemdziesiątych i dziewięćdziesiątych XX w. doprowadziła do zmian uwarunkowań społeczno-gospodarczych. Wprowadzenie swobody aktywności obywateli zarówno na polu działalności społecznej, jak i otwartym, wolnym rynku go- 
spodarki kraju spowodowało intensyfikację procesów demokratyzacji i komercjalizacji. Przeobrażenia ustroju państwa polskiego umożliwiły jego włączenie w obieg gospodarki światowej, co w efekcie wpłynęło nie tylko na wymianę procesów na poziomie terytorium kraju, lecz także w wymiarze ogólnoświatowym. Procesy, jakie wystapiły w Polsce wskutek postępujacych interakcji społecznych i gospodarczych, spowodowały pojawienie się takich zjawisk, jak: globalizacja, postęp techniczny i technologiczny, reorganizacja sektorów działalności i wzrost znaczenia usług, w szczególności informatycznych, liberalizacja polityki społecznej, integracja polityczna i gospodarcza czy reorientacja kultury i struktur demograficznych ${ }^{2}$.

W Raporcie Banku Światowego za 2009 r. Reshaping Economic Geography (w ramach cyklu World Development Report) jego autorzy wyszczególnili, biorąc pod uwagę okres kryzysu i niepewności, trzy następujące wymiary współczesnego rozwoju społeczno-gospodarczego:

- nierówność terytorialna - koncentracja aktywności gospodarczej w wybranej lokalizacji (przestrzeni);

- sprzężenie zwrotne - kompatybilność obszaru, na którym występuje koncentracja działalności gospodarczej z konwergencją poziomu konsumpcji rozumianej jako zamożność;

- efekt sasiedztwa - realizacja integracji przestrzennej w celu kształtowania długookresowej konwergencji korzyści w przestrzeni ${ }^{3}$.

Rezultatem strukturyzacji i rozwoju sieci gospodarczej jest narastanie różnego rodzaju powiązań i relacji zmierzających do osiagnięcia synergii między poszczególnymi punktami sieci w czasoprzestrzenni, co w konsekwencji prowadzi do segmentacji procesów rozwoju. Intensyfikacja zmian występujących w otoczeniu tzw. punktów inicjuje koncentrację aktywności gospodarczej w obszarze ich działalności (nowe relacje oraz formy i sposoby działalności) oraz wzrost ich funkcji, w wyniku czego powstają nowe formy urbanizacji określane mianem metropolizacji (metropolii) ${ }^{4}$.

$\mathrm{W}$ ciagu najbliższych lat przewiduje się przyspieszenie zmian $\mathrm{w}$ polskiej przestrzeni związanych z rozwojem i modernizacja środowiska społeczno-gospodarczego, wynikających m.in. z postępującej koncentracji funkcji ośrodków krajowych i europejskich zlokalizowanych w podstawowej sieci ośrodków wzrostu oraz intensyfikacji powiązań funkcjonalnych między nimi, czy też osiedlania się ludności w ośrodkach rozwijających się przy jednoczesnym odpływie ludności z terenów wiejskich oraz małych ośrodków miejskich ${ }^{5}$.

We współczesnym społeczeństwie - opartym na sieciowej strukturze przepływów: kapitału, technologii, wiedzy czy informacji - metropolie, według Manuela Castellsa, są najwyższą formę organizacji przestrzeni jako węzły, w których koncentrują się te przepływy w ramach swojej globalnej sieci. Me-

2 E. Szafrańska, Geografia społeczna miast. Struktury społeczno-przestrzenne, w: S. Liszewski (red.), Geografia urbanistyczna, WN PWN, Warszawa 2012, s. 164.

${ }^{3}$ S. Korenik, Region ekonomiczny $w$ nowych realiach społeczno-gospodarczych, CeDeWu, Warszawa 2011, s. 113.

${ }^{4}$ Ibidem, s. 28 i 29.

5 Koncepcja Przestrzennego Zagospodarowania Kraju 2030, Ministerstwo Rozwoju Regionalnego, Warszawa 2012, s. 10. 
tropolia stanowi swoistego rodzaju inkubator, w którym zachodzi akumulacja oraz zarządzanie informacja, wymagajacy wyposażenia w odpowiedni poziom: infrastruktury, usług i środowiska, gwarantujaccy optymalne otoczenie dla realizacji funkcji ${ }^{6}$.

Pojęcie „metropolia” oznacza: „najważniejsze miasto danej prowincji lub kraju, główny ośrodek kulturalny, gospodarczy itp.; stolica”. Słowo metropolia pochodzi od starogreckiego mētrópolis, które w starożytnej Grecji oznaczało miasto-państwo macierzyste w stosunku do założonego przez nie miasta-kolonii, powiąanych wzajemnie stosunkami gospodarczymi oraz religią i kultura; z kolei z punktu widzenia etymologii języka łacińskiego: metropolis oznacza miasto stołeczne ${ }^{7}$.

Początków metropolizacji (w sensie semantycznym i funkcjonalnym) należy doszukiwać się w starożytności, np. Babilon, Rzym czy Konstantynopol, a pojawiajace się jej nowe funkcje i znaczenie wynikają ze zmienionych uwarunkowań. Globalizacja zjawisk społeczno-gospodarczych, a także szybki rozwój cywilizacji technicznej determinują siłę napędowa, dynamikę i skalę rozprzestrzeniania się metropolizacji. Współcześnie postępująca metropolizacja przestrzeni, rozpatrywana jako odrębne zjawisko bądź kolejna, nowa faza urbanizacji, jest znacznie odmienna pod względem ilościowym i jakościowym od wcześniej zachodzących procesów urbanizacji ${ }^{8}$.

Według Tadeusza Markowskiego: „Metropolizacja przestrzeni jest procesem przekształcania się przestrzeni miejskich polegajacym na zmianie relacji między miastem centralnym a jego zapleczem. Zmiana relacji polega na osłabieniu lub zerwaniu związków gospodarczych miasta z otaczającym regionem i zastapieniu ich więziami z innymi metropoliami w skali kontynentalnej lub światowej. Rola regionu ogranicza się do pełnienia funkcji mieszkaniowych i rekreacyjnych dla mieszkańców metropolii, zaś nieciagłość przestrzeni oznacza, że "sąsiadem« w sensie gospodarczym i społecznym nie jest już otaczający region, lecz położona - często w dużej odległości - inna metropolia"9.

Proces metropolizacji jest rozpatrywany w dwóch różnych aspektach, tj.:

- inicjowania na podstawie funkcjonujacych, o określonych cechach i potencjale, niektórych wielkich miast metropolii-sieci ośrodków, oddziałujących na główne procesy rozwoju współczesnej cywilizacji, m.in. przez zarządzanie przepływami w skali globalnej (świata, kontynentu lub subkontynentu), a także istniejącej kooperacji w zakresie sieci kontaktów i przepływów, w części uniezależnionej od regionalnego otoczenia (rola metropolii w międzynarodowej sieci: gospodarki, kultury, polityki itd.);

${ }^{6}$ J. Lendzion, Znaczenie obszarów metropolitalnych $i$ ich otoczenia oraz wspótczesnych procesów metropolizacyjnych w ksztattowaniu polityki regionalnej Państwa, Ekspertyza przygotowana na zamówienie Departamentu Polityki Regionalnej Ministerstwa Gospodarki i Pracy (Umowa BAB. I. 374 / F z dn. 3 grudnia 2004 r.) dla potrzeb tworzenia Narodowej Strategii Rozwoju Regionalnego, Gdynia 2005, s. 6.

${ }^{7}$ Stownik wyrazów obcych, WN PWN, Warszawa 1995, s. 715, s.v.

8 T. Markowski, T. Marszał, Metropolie. Obszary metropolitalne. Metropolizacja. Problemy i pojęcia podstawowe, Komitet Przestrzennego Zagospodarowania Kraju PAN, Warszawa 2006, s. 10.

9 T. Markowski, Funkcje metropolitalne pięciu stolic województw wschodnich, www.mrr. gov.pl/rozwoj_regionalny/poziom_regionalny/strategia_rozwoj_polski_wschodniej_do_2020/dokumenty/Documents/17doccd2c3f14e-d3893369e56d59849cMarkowski.pdf, s. 324 i 325 [dostęp: 10.05.2015]. 
- kształtowania obszarów metropolitalnych w bliskim zasięgu oddziaływania wielkich miast metropolii - sieci ośrodków (ok. 30-40 km), w wyniku silnego różnicowania się w sposób selektywny przestrzeni regionalnej złożonej z mniejszych miast i osiedli, co w konsekwencji wywiera często negatywny wpływ na dalsze otoczenie regionalnego zaplecza ${ }^{10}$.

Metropolizacja przestrzeni jest nierozerwalnie związana $\mathrm{z}$ funkcjonowaniem metropolii, metropolizacja bowiem formuje metropolie, a te determinuja obszar metropolitalny. Istnienie metropolii jest warunkiem zainicjowania procesu metropolizacji przestrzeni usytuowanej w otoczeniu metropolii (otoczeniu przestrzeni metropolii, zarówno bezpośrednio sąsiadującemu z metropolia, jak i obejmującemu większy wymiar - kraj, kontynent, świat) ${ }^{11}$.

Problemem procesu metropolizacji jest narastająca dysproporcja rozwoju między obszarem metropolitalnym a zmarginalizowanymi - z reguły słabiej rozwiniętymi - obszarami znajdującymi się poza nim. W szczególnie trudnej sytuacji znalazły się pozametropolitalne ośrodki postindustrialne oraz obszary wiejskie, które z uwagi na destruktywne czynniki ich morfologii społeczno-gospodarczej nie stanowiły alternatywnie atrakcyjnej oferty względem metropolii dla inwestorów oraz wyspecjalizowanych usług, wiedzy i innowacji. Restrukturyzacja tych obszarów prowadziła z reguły do zaniku działalności gospodarczej w regionie i braku powstawania w jej miejsce nowych ośrodków, w wyniku czego następowała stagnacja gospodarcza i wzrastało bezrobocie ${ }^{12}$.

Otoczenie ery postindustrialnej, w szczególności reorganizacja podstaw ekonomiki miast, ukształtowało nowe role, jakie pełnia miasta metropolitalne. Proces suburbanizacji polegajacy na morfologicznym upodabnianiu się strefy wokół metropolii do jego centrum (miasta), jak również wzrost zachodzących między nimi interakcji i funkcjonalnych powiązań społeczno-gospodarczych, powoduje formowanie się obszarów metropolitalnych (aglomeracji funkcjonalnych). Aglomeracja funkcjonalna posiada region metropolitalny oznaczajacy strefę oddziaływania usytuowaną wokół obszaru metropolitalnego, jednakże dla rozwoju metropolii istotniejsza pozostaje jej pozycja w sieci miast, w tzw. otoczeniu globalnym (proces globalizacji) ${ }^{13}$.

\section{OBSZARY METROPOLITALNE W POLSCE W LATACH 2010-2013}

Rola jednostek samorządu terytorialnego w procesie kształtowania obszarów metropolitalnych ma szczególne znaczenie, tym bardziej że to te podmioty przede wszystkim na poziomie gmin, powiatów oraz miast na prawach powiatu pełnią funkcje zarządcy przestrzeni publicznej, tworząc, we współpracy z otoczeniem jednostek wiedzy i biznesu, środowisko sieci powiązań w skali

\footnotetext{
${ }^{10}$ J. Lendzion, op. cit., s. 4 i 5.

11 T. Markowski, T. Marszał, op. cit., s. 11.

12 J. Kaźmierski, Rozwój i zarzqdzanie strukturami klastrowymi w regionie, Wyd. UÆ, Łódź 2012 , s. 89 i 90.

${ }^{13}$ D. Hołuj, A. Hołuj, Miasta metropolitalne jako bieguny rozwoju $w$ gospodarce postindustrialnej, „Folia Oeconomica Bochniensia” 2006, nr 4, s. 54 i 55.
} 
mikro (sieci wewnętrznej - regionalnej) i makro (sieci zewnętrznej: ponadregionalnej, państwa, międzynarodowej).

Pojęcie obszaru metropolitalnego zostało wprowadzone do polskiej legislacji wraz z uchwalniem ustawy o planowaniu i zagospodarowaniu przestrzennym w 2003 r. W ramach przedmiotowego aktu ustawodawczego obszar metropolitalny zdefiniowano jako „[...] obszar wielkiego miasta oraz powiązanego z nim funkcjonalnie bezpośredniego otoczenia, ustalony w koncepcji przestrzennego zagospodarowania kraju" (art. 2 pkt 9) ${ }^{14}$. Obszary metropolitalne stanowiły element, który winien być obligatoryjnie wyodrębniany, tak w Koncepcji przestrzennego zagospodarowania kraju, jak i w planie zagospodarowania przestrzennego województwa (w formie planu zagospodarowania przestrzennego obszaru metropolitalnego jako część planu zagospodarowania przestrzennego województwa) ${ }^{15}$. Na podstawie ustawy o zmianie ustawy o zasadach prowadzenia polityki rozwoju oraz niektórych innych ustaw, która weszła w życie 8 kwietnia 2014 r., uchylono pojęcie obszaru metropolitalnego, jednocześnie wprowadzając pochodną definicję miejskiego obszaru funkcjonalnego ośrodka wojewódzkiego, określanego mianem [...] obszaru funkcjonalnego obejmujacego miasto będące siedzibą władz samorządu województwa lub wojewody oraz jego bezpośrednie otoczenie powiązane $\mathrm{z}$ nim funkcjonalnie"16.

Reforma ustroju podziału terytorialnego wdrożona 1 stycznia $1999 \mathrm{r}$., postępująca reorganizacja systemu polityki społeczno-gospodarczej państwa, konsekwencje wynikające z przystapienia Polski do Unii Europejskiej w 2004 r., w szczególności procesy konwergencji, a także interdyscyplinarny rozwój wiążący się z narastającymi globalizacja, konkurencyjnościa, intensyfikacją rozprzestrzeniania się technologii, migracji, mobilności pracy itd. doprowadziły m.in. do ukształtowania się obszarów metropolitalnych jako ośrodków - centrów rozwoju nie tylko na poziomie regionu, lecz także kraju. Obszary metropolitalne implikowane w rezultacie rozrostu funkcji miast - centrum - i ich oddziaływania na tereny zlokalizowane w bezpośrednim sąsiedztwie spowodowały wyodrębnienie się nowego podmiotu zarządzania przestrzenia publiczną. Podmiot ten prowadzi działalność we współudziale jednostek samorządu terytorialnego różnych szczebli, które zadeklarowały wolę fakultatywnego uczestnictwa w organizacji obszaru metropolitalnego. Zrzeszanie się samorządów lokalnych w obszarze metropolitalnym - z jednej strony - wywiera pozytywny wpływ na dążenie do realizacji zintegrowanego zrównoważonego rozwoju środowisk (przestrzeni, społeczeństwa, gospodarki, kultury, nauki itd.), przy założeniu optymalizacji działań mających na celu efektywne, skuteczne i oszczędne gospodarowanie zasobami (materialnymi i niematerialnymi), w związku z realizacją zadań o charakterze użyteczności publicznej oraz kreowaniu otoczenia i wspieraniu aktywności podmiotów biznesu i nauki.

${ }_{14}$ Ustawa z 27 marca 2003 r. o planowaniu i zagospodarowaniu przestrzennym, Dz. U. 2003, Nr 80, poz. 717 ze zm.

${ }^{15}$ Ibidem, art. 39 ust. 3 pkt 4 i ust. 6 oraz art. 47 ust. 2 pkt 1.

${ }^{16}$ Ustawa z 24 stycznia 2014 r. o zmianie ustawy o zasadach prowadzenia polityki rozwoju oraz niektórych innych ustaw (Dz. U. 2014, poz. 379), art. 7 pkt 1 lit. a i b i pkt 3 lit. a-c. 
Do chwili obecnej nie zostały sformułowane ramy prawne funkcjonowania obszarów metropolitalnych (poza określeniem pojęcia w sensie urbanistycznym), a mimo to ich inicjacja i rozwój zachodziły w toku samodzielnej działalności samorządów lokalnych i istniejących możliwości wzajemnej, dobrowolnej ich współpracy, np. w formie stowarzyszeń.

W wyniku przeglądu procesów legislacyjnych, jakie miały miejsce w Polsce po 2004 r., należy wskazać na dwa projekty ustaw, które w założeniu porządkowałyby kwestie dotyczące obszarów metropolitalnych. Pierwszy z projektów to dokument z 2008 r. stanowiący propozycje ustawy o rozwoju miast, centrach rozwoju regionalnego i obszarach metropolitalnych. W projekcie ustawy podjęto próbę uporządkowania takich elementów, jak: polityka miejska państwa, metropolie, obszary metropolitalne, w tym: charakterystyka podmiotu (definicja, granica terytorium itd.), zakres działalności (funkcje i zadania), metodologię organizacji i zarządzania (tworzenie zespołów metropolitalnych) ${ }^{17}$. Drugi projekt aktu normatywnego to ustawa z 30 lipca 2013 r. o powiecie metropolitalnym, opracowana i przedłożona przez Klub Parlamentarny Platforma Obywatelska. Analiza doświadczeń państw europejskich wskazuje, że podstawowymi modelami ustroju metropolitalnego są rozwiąania oparte na dobrowolnej współpracy jednostek samorządu terytorialnego lub powołanie jednostek ogólnometropolitalnych (powiaty metropolitalne, regiony metropolitalne) ${ }^{18}$.

W dalszej części artykułu zostały wykorzystane podstawowe dane statystyczne zgromadzone na podstawie opracowań wykonanych przez Główny Urząd Statystyczny w ramach tzw. cyklu: „Vademecum Samorządowca” za lata 2010-2012, w których oprócz podstawowych form jednostek samorządu terytorialnego wyróżniono 11 obszarów metropolitalnych w Polsce (w analizie odstapiono od uwzględnienia danych dotyczacych obszaru aglomeracji trójmiejskiej na rzecz aglomeracji gdańskiej). Dane udostępnione przez GUS zostały wykorzystane na potrzeby przeprowadzonego badania z uwagi na ich ujednolicony w odniesieniu do każdego ze wskazanych obszarów metropolitalnych oraz uporządkowany zakres prezentowanych informacji. Wybór podmiotów do badania wynika z prawno-organizacyjnej delimitacji obszarów metropolitalnych w ramach przedstawionych opracowań statystycznych (Vademecum Samorządowca). Z punktu widzenia zachodzacych procesów metropolizacji w Polsce może wzbudzać kontrowersje uwzględnienie przez autora kieleckiego i opolskiego obszaru metropolitalnego zamiast np. łódzkiego czy wrocławskiego, u których dostrzega silniejsze funkcje metropolitalne ${ }^{19}$. Autor w badaniu odwołał się do danych GUS-u, prezentujących w ujęciu statystycznym za lata 2010-2012 obszary metropolitalne o unormowanej prawno-organizacyjnej formie działalności, np. umowa partnerstwa, stowarzyszenie.

Wykres 1 prezentuje liczbę samorządów lokalnych różnego stopnia wchodzących w skład 10 poszczególnych obszarów metropolitalnych w $2012 \mathrm{r}$.

${ }^{17}$ Projekt ustawy o rozwoju miast, centrach rozwoju regionalnego i obszarach metropolitalnych z $2008 \mathrm{r}$.

18 Projekt ustawy o powiecie metropolitalnym z 30 lipca 2013 r., s. 22 i 34.

${ }^{19}$ Koncepcja Przestrzennego Zagospodarowania Kraju 2030, s. 44, rys. 5. 
w Polsce. Łączna liczba wszystkich jednostek wynosi 311 (ok. 11\% łącznej liczby jednostek wszystkich szczebli samorządu). Największą liczbą jednostek samorządu terytorialnego w strukturze wyróżniają się obszary metropolitalne: lubelski, krakowski i gdański; najmniejszą liczbą podmiotów w składzie zawieraja: górnośląski, szczeciński i kielecki, jednakże w wypadku górnośląskiego obszaru tworzy go 9 miast na prawach powiatu o liczbie ludności powyżej 100 tys. osób. Liczba podmiotów wchodzacych w skład wybranych obszarów metropolitalnych nie odzwierciedla rozmiaru czy potencjału społeczno-gospodarczego, np. górnośląski obszar metropolitalny, w skład którego wchodzi najmniejsza liczba jednostek, obejmuje zasięgiem również jedną z mniejszych powierzchni, z kolei odznacza się największą liczbą ludności i osób pracujących po warszawskim obszarze metropolitalnym (w granicach obszaru jest zlokalizowana największa liczba miast powyżej 100 tys. mieszkańców). Lubelski obszar metropolitalny składający się z największej liczby podmiotów zajmuje, za warszawskim i gdańskim, znaczną powierzchnię terytorium, zamieszkiwaną przez jedną z najmniejszych liczbę ludności. Największa koncentracja ludności (ponad 1 mln mieszkańców), w tym osób pracujących (ponad 350 tys.), występuje w poznańskim obszarze metropolitalnym, zajmujacym najmniejsza powierzchnię.

\section{Wykres 1}

Liczba podmiotów wchodzących w skład wybranych obszarów metropolitalnych funkcjonujących w Polsce w 2012 r.

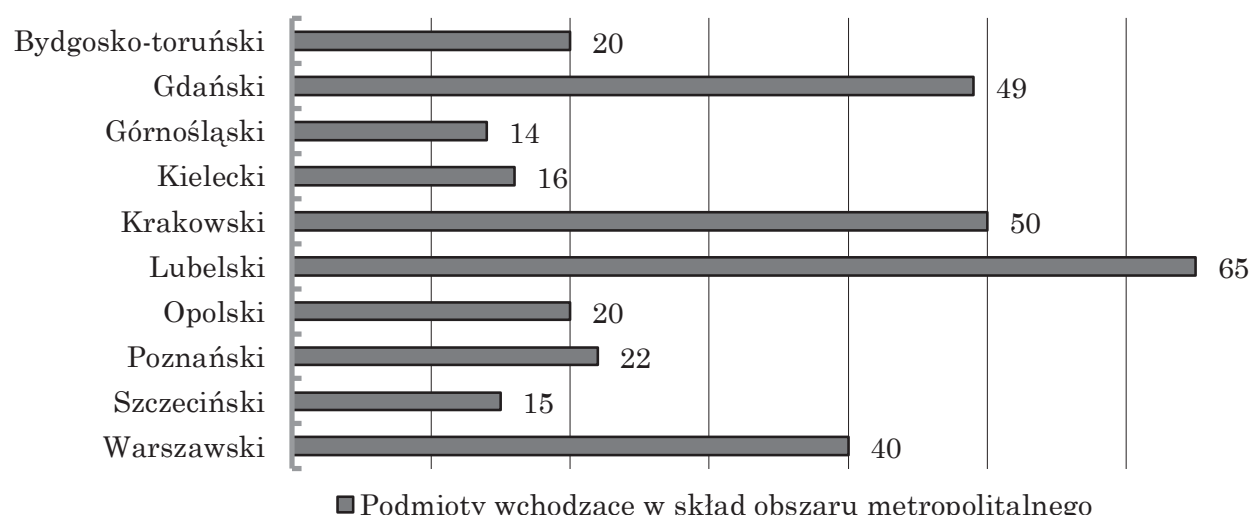

Źródło: opracowanie własne na podstawie danych GUS-u.

Brak uregulowań prawnych dotyczących obszarów metropolitalnych w Polsce powoduje nie tylko zróżnicowanie w ich formach prawno-organizacyjnychpowiązań oraz rodzajach podmiotów wchodzacych w ich skład, ale również celów, do jakich zostały powołane. 


\section{Wykres 2}

Dziesięć najczęściej występujących celów działania, do jakich zostały powołane obszary metropolitalne w Polsce

Podnoszenie konkurencyjności obszaru

Współdziałanie z jednostkami samorządu terytorialnego, w tym społecznościami lokalnymi i regionalnymi innych państw oraz organami administracji rządowej

Wypracowanie wspólnej koncepcji zagospodarowania przestrzennego

Programy obsługi inwestorów, tworzenia inkubatorów przedsiębiorczości oraz rozwoju gospodarczego

Realizacja zadań objętych wspólną strategia rozwoju miast przez gminy członkowskie na podstawie stosownych porozumien

Zintegrowane projekty inwestycyjne finansowane ze środków UE

Kreowanie wspólnego programu promocji obszaru; otwartość na imigrantów oraz promocja unikatowych w skali Europy walorów przyrodniczych

Usprawnienie transportu publicznego w obszarze w zakresie szybkości przemieszczania się

Wyrażanie opinii dotyczących procesów legislacyjnych i decyzyjnych w sprawach objętych przedmiotem zainteresowania

Polityka ochrony krajobrazu i środowiska

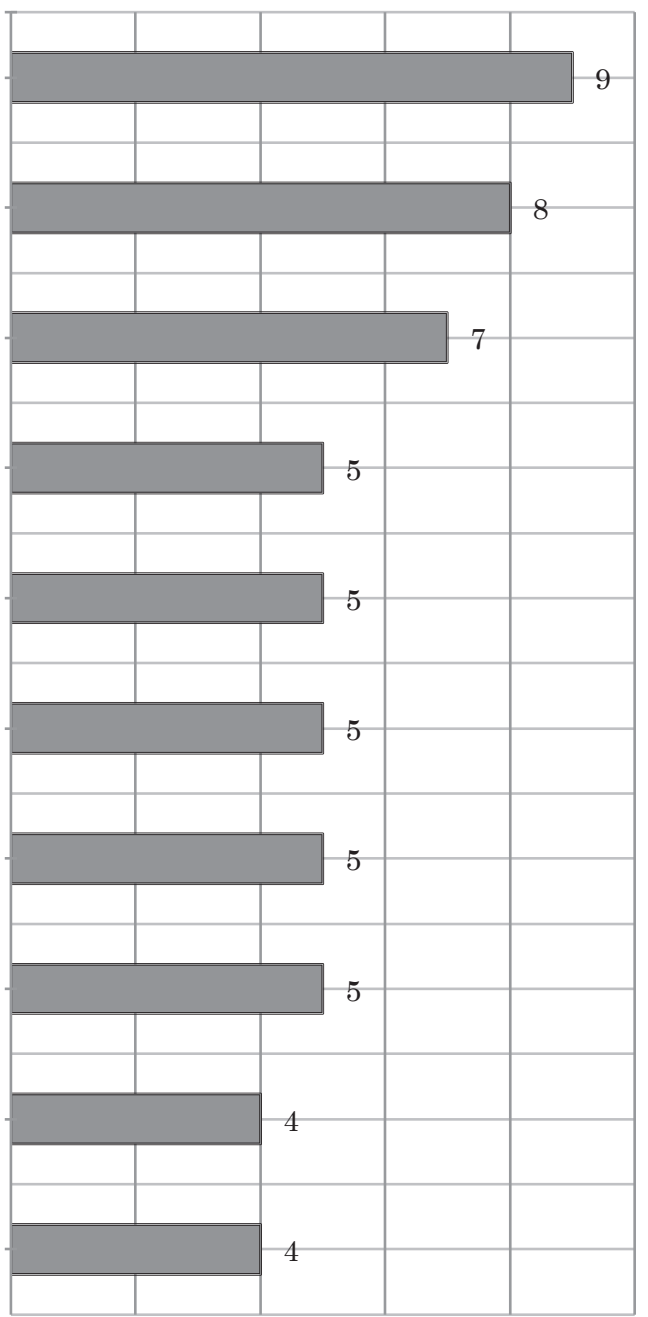

口iczba podmiotów

Na wykresie 2 przedstawiono liczbę podmiotów (obszarów metropolitalnych), które jako podstawę swojej działalności wskazują realizację zdefiniowanego celu (na potrzeby analizy wyszczególniono 10 najczęściej wskazywanych celów działalności przez obszary metropolitalne). Zgodnie z wynikami analizy wykresu 2 najczęstszą przyczyną powołania do działalności instytucji obszaru metropolitalnego, niezależnie od jej formy, były: dążenie do podnoszenia 
konkurencyjności regionu (9 z 10 obszarów), współdziałanie z jednostkami samorządu terytorialnego, w tym także społecznościami innych państw oraz organami administracji rządowej (8 z 10 obszarów), jak również wypracowanie wspólnej koncepcji zagospodarowania przestrzennego (7 z 10 obszarów). Cele działalności obszarów metropolitalnych wynikają z potrzeby rozwiązania współczesnych problemów, z jakimi przychodzi zmierzyć się zarówno aglomeracjom miejskim, jak i samorządom lokalnym.

Powierzchnia terytorium jednostek samorządu terytorialnego wchodzących w skład 10 obszarów metropolitalnych w Polsce odpowiada średnio ok. 16\% terytorium województw, w których znajdują się te obszary (2012). Największa powierzchnię województwa w Polsce w 2012 r. zajmuje gdański obszar metropolitalny (ok. 37\% powierzchni terytorium województwa pomorskiego), z kolei najmniejszą powierzchnię w stosunku do powierzchni terytorium województwa zajmuje poznański obszar metropolitalny (w 2012 - ok. 0,10\% powierzchni województwa wielkopolskiego).

Na wykresie 3 zilustrowano w sposób graficzny liczbę oraz strukturę ludności zamieszkującej na terenie 10 obszarów metropolitalnych w Polsce w latach 2010-2012. Wyniki analizy pozwalają stwierdzić, że liczba ludności zamieszkujacej zdefiniowane obszary metropolitalne wynosiła od ok. 11,76 mln w 2010 do ok. 11,85 mln osób w 2012 r. (biorąc pod uwagę ogólną liczbę ludności Polski w latach 2010-2012, obszary metropolitalne zamieszkuje ok. 31\% ludności Polski).

\section{Wykres 3}

Liczba oraz struktura ludności w wieku przedprodukcyjnym, produkcyjnym i poprodukcyjnym zamieszkującej na terenie obszarów metropolitalnych w Polsce w latach 2010-2012

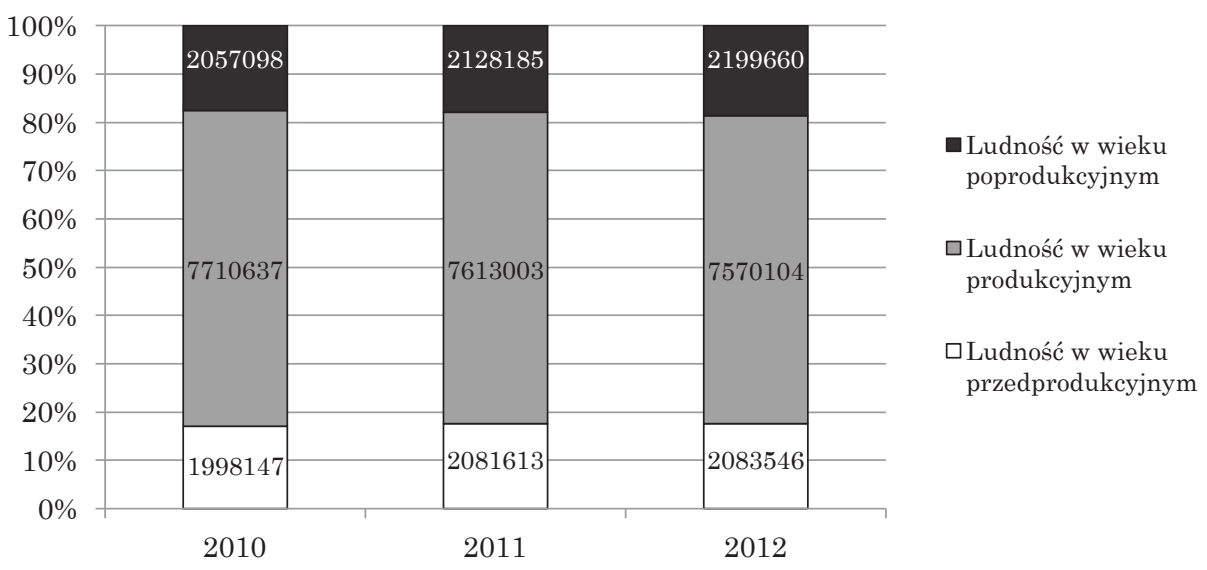

Źródło: opracowanie własne na podstawie danych GUS-u.

W rezultacie analizy wykresu $3 \mathrm{w}$ zakresie struktury ludności zamieszkującej obszary metropolitalne można zauważyć tendencje wzrostu liczby ludności w wieku przedprodukcyjnym (ok. 16,98\% w 2010 i ok 17,58\% w 2012 ogól- 
nej liczby ludności) i poprodukcyjnym (ok. 17,48\% w 2010 i ok. 18,56\% w 2012 ogólnej liczby ludności). Liczba ludności w wieku produkcyjnym zmniejszała się w latach 2010-2012 i wynosiła ok. 65,53\% w 2010 i ok. 63,86\% w 2012 ogólnej liczby ludności.

Wykres 4 prezentuje liczbę osób pracujacych i bezrobotnych na terenie, na którym są zlokalizowane obszary metropolitalne w Polsce w latach 2010-2012 w odniesieniu do informacji wyszczególnionych na poziomie: województw, obszarów metropolitalnych i miast na prawach powiatu o liczbie ludności powyżej 100 tys. Dokonując analizy wykresu 4, podstawowym spostrzeżeniem jest fakt, że to w miastach na prawach powiatu koncentruje się aktywność zawodowa społeczeństwa obszarów metropolitalnych (liczba osób pracujących). Zauważalna tendencja w zakresie liczby osób pracujacych to jej wzrost w 2011 r. w stosunku do 2010 oraz spadek w 2012 w odniesieniu do 2011.

\section{Wykres 4}

Liczba pracujaccych i bezrobotnych na terenie, na którym są zlokalizowane obszary metropolitalne w Polsce w latach 2010-2012

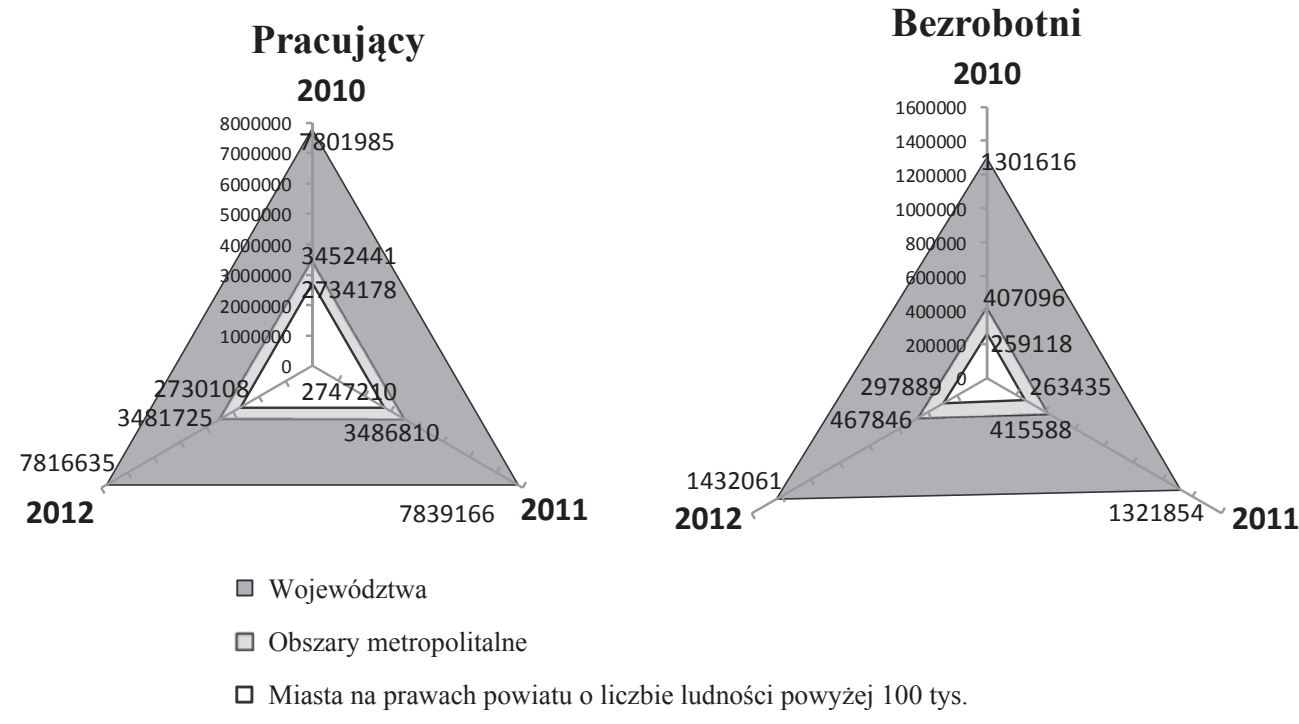

Źródło: opracowanie własne na podstawie danych GUS-u.

Liczba osób pracujaccych w ramach obszaru metropolitalnego stanowi ok. 46\% liczby osób w wieku produkcyjnym tego terenu (2012). Analizując liczbę osób bezrobotnych, warto zauważyć - po pierwsze - że liczba osób bezrobotnych na terenie danego województwa zdecydowanie nie jest determinowana liczba osób bezrobotnych z obszaru metropolitalnego oraz miast na prawach powiatu. Po drugie - znacznie mniejsza liczba osób bezrobotnych występuje na terenie miast na prawach powiatu wchodzaccych w skład obszaru metropolitalnego 
aniżeli w granicach samorządów lokalnych szczebla gmin i powiatów usytuowanych poza wielkimi miejskimi aglomeracjami. Liczba osób bezrobotnych w ramach obszaru metropolitalnego stanowi ok. 6\% liczby osób w wieku produkcyjnym tego terenu (2012).

Ukształtowanie się obszarów metropolitalnych w Polsce po 1989 r. nastapiło samoczynnie, jako efekt zmian ustroju politycznego oraz przemian społeczno-gospodarczych. Brak regulacji prawnych dotyczących obszarów metropolitalnych nie spowodował zahamowania budowy sieci aglomeracji miejsko-wiejskich, lecz przeciwnie, udostępnił takie otoczenie prawno-ekonomiczne, które pozwoliło na suwerenne i samodzielne powołanie organizacji metropolitalnych, wynikające $\mathrm{z}$ narastających potrzeb w dążeniu do równoważenia rozwoju środowiska. Niezwykle ważne jest, aby w nowej perspektywie finansowej spójna polityka rządu oraz samorządów wspierała inicjację czynników determinujących rozwój obszarów metropolitalnych.

\section{DETERMINANTY ROZWOJU OBSZARÓW METROPOLITALNYCH W PERSPEKTYWIE 2014-2020}

Perspektywa 2014-2020 otwiera nowe wyzwania przed Polska, wiążące się przede wszystkim z postępująca konwergencją otoczenia prawnego, społecznego i gospodarczego państwa do warunków, jakie istnieją w krajach wysoko rozwiniętych Europy Zachodniej, i możliwością wykorzystania na te cele zewnętrznych środków finansowych z budżetu Unii Europejskiej. Szeroko rozumiany postęp cywilizacyjny, jaki nastapił w Polsce po 1989 r., a w szczególności w ostatnim dziesięcioleciu (począwszy od 2004), spowodował, że stopień skomplikowania zjawisk i problemów, z którymi przyjdzie zmierzyć się administracji publicznej w horyzoncie do 2020 r., jest znacznie większy, aniżeli miało to miejsce dotychczas. Polityka zrównoważonego rozwoju w dążeniu do osiagnięcia coraz to wyższego poziomu jakości środowiska (społecznego, naturalnego, gospodarczego itd.) będzie zmuszona do rozwiązywania nieprzemijającego problemu ograniczonej ilości i/lub jakości zasobów (np. środków finansowych) niezbędnych do zaspokojenia nieograniczonej liczby i/lub narastających oczekiwań względem jakości potrzeb o charakterze użyteczności publicznej (np. większy dostęp do usług medycznych oraz wzrost ich jakości).

Ważnym narzędziem budowania platformy współpracy między jednostkami samorządu terytorialnego w perspektywie do 2020, w szczególności zrzeszonych w ramach obszarów metropolitalnych, sa zintegrowane inwestycje terytorialne (ZIT), wynikajace z działań lub poddziałań prowadzonych w zakresie co najmniej dwóch osi priorytetowych regionalnego programu operacyjnego (RPO), finansowanych z dwóch funduszy strukturalnych (RPO obejmuje realizację ZIT na terenie miast stanowiących siedzibę władz samorządu województwa lub wojewody, a także obszarów powiązanych z nimi funkcjonalnie ${ }^{20}$.

${ }^{20}$ Ustawa z 11 lipca 2014 r. o zasadach realizacji programów w zakresie polityki spójności finansowanych w perspektywie finansowej 2014-2020 (Dz. U. 2014, poz. 1146), art. 30. 
Przyjęta wizja rozwoju Polski wiąże się z realizacja celów i zadań zmierzających do integracji funkcjonalnej z czołowymi centrami (miastami i regionami) Unii Europejskiej przez intensyfikację procesów synergii i kształtowanie sieci powiązań między głównymi polskimi miastami. W prowadzeniu takiej polityki upatruje się osiagnięcie niezbędnej masy krytycznej (funkcji: gospodarczych, społecznych i kulturowych), dającej szansę na konkurowanie o ograniczone zasoby (czynniki rozwoju) oraz zbudowanie przestrzeni do wzajemnie korzystnej współpracy z innymi krajami i regionami Unii Europejskiej. Równomierna lokalizacja w przestrzeni miast odznaczających się znacznym potencjałem, stanowiących sieć powiązań wraz z przysposobieniem do sieci ośrodków o niższej randze osadniczej (wzrost integracji funkcjonalnej) będzie wpływać na zdolność rozwoju mniejszych miast oraz ich peryferyjnych obszarów wiejskich. Optymalna sieć powiązań miast odgrywa rolę generatora samoistnych bodźców wpływających na rozwój otoczenia, a w konsekwencji stwarza warunki do dynamizowania rozwoju kraju, w pełni wykorzystując potencjał obszarów metropolitalnych oraz sprzyjając spójności terytorialnej i przeciwwadze dla obecnie wzrastajacej dominacji stolicy Polski ${ }^{21}$.

Prowadzona dotychczas debata na temat procesów metropolizacji występujących w Polsce nie przyniosła żadnych efektów, z kolei opracowane projekty aktów prawnych otrzymały negatywne oceny środowisk będaccych inicjatorami kształtowania obszarów metropolitalnych (przede wszystkim jednostek samorządu lokalnego). Na podstawie wykonanych badań i analiz w toku opracowywania tzw. Zielonej księgi ${ }^{22}$ podsumowano doświadczenia w zakresie rozważań nad organizacją i funkcjonowaniem obszarów metropolitalnych w Polsce. $\mathrm{W}$ wyniku zgromadzonych wniosków i opinii została przygotowana tzw. Biała księga, zawierająca m.in. konkretnie sformułowane rekomendacje na potrzeby budowania środowisk rozwoju obszarów metropolitalnych w Polsce w przyszłości.

Badaniem planu realizacji polityki rozwoju Polski objęto cztery podstawowe dokumenty strategii rozwoju kraju, tj. długo- i średniookresowej strategii kraju, koncepcji przestrzennego zagospodarowania kraju oraz strategii rozwoju regionalnego. W wyniku analizy podstawowych celów strategicznych, a także planowanych kierunków interwencji państwa w ramach polityki rozwoju Polski w horyzoncie do 2030 r., koncentrujących się na determinantach wzrostu znaczenia obszarów metropolitalnych, wyodrębniono dwa zbiory sformułowanych celów w zakresie wspierania rozwoju obszarów metropolitalnych.

Pierwszy ze zbiorów celów (w tym kierunków interwencji) obejmuje przede wszystkim założenia dotyczące integracji obszarów miejskich z wiejskimi przez rozwiązania prawne, instytucjonalne i organizacyjne, jak również wykorzystanie i wspieranie wewnętrznego potencjału rozwojowego regionu (obsza$\mathrm{ru})$, m.in.:

- utrzymanie i rozwój powiązań funkcjonalnych między głównymi ośrodkami sieci osadniczej, w szczególności integracja i usprawnienie sieci transportu oraz zwiększenie dostępności komunikacyjnej (sfera planowania);

${ }^{21}$ Koncepcja..., op. cit., s. 11.

22 Zielona księga obszarów metropolitalnych, Ministerstwo Administracji i Cyfryzacji, Warszawa 2012. 
- wspieranie rozwoju funkcji metropolitalnych oraz integracja obszarów funkcjonalnych zarówno głównych, jak i słabszych ośrodków miejskich, wzmocnienie rozwoju ośrodków o znaczeniu lokalnym;

- wprowadzenie ram organizacyjnych i prawnych, w tym wdrożenie ustawy metropolitalnej;

- kreowanie otoczenia sieci współpracy dla wsparcia kapitału społecznego, w tym wspieranie współpracy i sieciowania ośrodków: nauki, administracji, edukacji, kultury itd. dla zwiększenia tempa dyfuzji wiedzy, know-how itd.;

- reorganizacja odpowiedzialności za zapewnienie i zarządzanie usługami publicznymi, dążenie do poprawy jakości zarządzania polityką publiczna.

Drugi zbiór zawiera cele skupiające się w orbicie działań związanych z integracją rozwiązań transportowych (infrastruktura), w tym transportu indywidualnego i publicznego zbiorowego, w szczególności w zakresie planowania i inwestycji w sprawne sieci komunikacji zapewniające koherencje obszarów wiejskich z miejskimi oraz płynność i bezpieczeństwo w ruchu na terenie miast, m.in.:

- dążenie do spójności terytorialnej przez rozbudowę powiązań infrastrukturalnych łączących ośrodki miejskie położone na obszarach peryferyjnych $\mathrm{z}$ siecią metropolii, w tym sukcesywne zwiększanie poprawy sieci transportowej do ośrodków wojewódzkich na obszarach o najniższej dostępności, przebudowa dróg przechodzących przez miasta i małe miejscowości oraz budowa obwodnic dużych miejscowości;

- wdrożenie technik sterowania i zarządzania ruchem w dużych miastach;

- wspieranie działań na rzecz upłynnienia ruchu i wzrostu jakości usług z zakresu transportu miejskiego, w szczególności przez koordynację środków transportu zbiorowego (dogodność przesiadek, integracja systemów taryfowych, podniesienie jakości oferty);

- wspieranie restrukturyzacji oraz rewitalizacji miast i innych obszarów pozbawionych dotychczasowych funkcji społeczno-gospodarczych.

Ponadto wizja rozwoju zagospodarowania przestrzeni Polski formułuje podstawowy zakres wzrostu już zidentyfikowanych oraz inicjację nowych sieci powiązań funkcjonalnych miast w 2030 r., w tym wyróżnia się następujące grupy ośrodków miejskich:

- stolica i największe polskie miasta, tj. Warszawa, aglomeracja górnoślaska (Górnośląski Zwiąek Metropolitalny), Kraków, Trójmiasto (Gdańsk - Sopot - Gdynia), Wrocław, Poznań, Szczecin i kształtujący się duopol Bydgoszcz - Toruń oraz Lublin;

- miasta wojewódzkie o znaczeniu krajowym, w których postępuje systematyczna koncentracja funkcji metropolitalnych o znaczeniu krajowym i międzynarodowym, tj. Białystok i Rzeszów, Opole, Olsztyn, Kielce, Gorzów Wielkopolski i Zielona Góra;

- miasta o znaczeniu regionalnym odznaczającej się podstawową siecią osadnicza, które stanowią ważny element równoważenia rozwoju kraju, tj. Częstochowa, Radom, Rybnik, Bielsko-Biała, Płock, Elblag, Wałbrzych, Włocławek, Tarnów, Koszalin, Legnica, Kalisz z Ostrowem Wielkopolskim, Grudziądz i Słupsk ${ }^{23}$.

${ }^{23}$ Koncepcja..., s. 41. 


\section{PODSUMOWANIE}

Najważniejsze wyzwania wiążące się z zarządzaniem przestrzenią publiczna, z jakimi przyjdzie zmagać się podmiotom sektora publicznego w Polsce $\mathrm{w}$ najbliższych latach, zostały zdiagnozowane na podstawie przeprowadzonych analiz na potrzeby przygotowania krajowych dokumentów strategicznych (długo- i średniookresowa strategia rozwoju kraju), z wykorzystaniem wniosków sformułowanych w przygotowanych już wcześniej raportach, np. Raport Polska 2011. Gospodarka - Spoteczeństwo - Regiony czy Raport o stanie przestrzennego zagospodarowania kraju „Polska przestrzen”” (2007). W wyniku opisu problemów zdefiniowano sposoby oddziaływania na środowisko i narzędzia umożliwiające świadome kształtowanie struktury polskiej przestrzeni społeczno-gospodarczej tak, aby wspomagała procesy samoczynnego rozprzestrzeniania się czynników rozwoju. W drodze prowadzonej polityki rozwoju nastapi koncentracja, m.in. na zarządzaniu rozwojem obszarów metropolitalnych ${ }^{24}$.

Rozpatrując opracowania w obszarze formułowania polityki rozwoju przez władzę centralną dostrzega się m.in. dążenie do wzmacniania znaczenia obszarów metropolitalnych - ośrodków potencjału i wzrostu postępu cywilizacyjnego - w nowej perspektywie finansowej w latach 2014-2020. W wyniku analizy opisanych problemów oraz zdefiniowanych na ich podstawie celów i zadań służących ich realizacji można określić najważniejsze czynniki, które będą miały wpływ na budowanie silnej pozycji obszarów metropolitalnych w sieci powiązań ośrodków miejskich wraz z ich obszarami funkcjonalnymi na poziomie krajowym i europejskim do $2020 \mathrm{r}$.

Wśród czynników oddziałujących na rozwój obszarów metropolitalnych w latach 2014-2020 należy wyszczególnić przede wszystkim:

- wdrażanie rozwiązań prawno-organizacyjnych optymalizujacych stopień osiagnięcia spójności w prowadzonej polityce rozwoju kraju na szczeblach: krajowym, ponadregionalnym, regionalnym i lokalnym w zakresie funkcjonowania podsektorów administracji rządowej i samorządowej (kaskadowy proces i układ definiowania i realizacji celów i zadań strategicznych w wielowymiarowych obszarach aktywności, tj. długo- i średniookresowe strategie rozwoju, strategie sektorowe, strategie samorządów lokalnych - województw, powiatów i gmin);

- wspieranie integracji w procesie kształtowania przestrzeni publicznej przez intensyfikację opracowań spójnych i racjonalnych koncepcji zagospodarowania przestrzennego: kraju, województwa i gmin, w tym także zwiększenie stopnia pokrycia planami zagospodarowania przestrzennego terytorium kraju i ograniczenie swobody urbanistycznej;

- opracowanie i wprowadzenie ram prawno-organizacyjnych wyznaczajacych otoczenie instytucjonalne zarządzania przestrzenią publiczną w obszarach funkcjonalnych, ze szczególnym wyodrębnieniem podmiotu i przedmiotu działalności dla obszarów metropolitalnych;

\footnotetext{
${ }^{24}$ Ibidem, s. 14.
} 
- tworzenia wysokiej jakości sieci powiązań transportowych, w tym wdrożenie rozwiązań organizacyjnych (zintegrowany system taryfowy i komunikacyjny) oraz rozbudowa i optymalizacja funkcjonalności systemów transportu (sprawny układ powiązań środków komunikacyjnych, np. zintegrowane węzły przesiadkowe), w szczególności zbiorowego transportu publicznego, na obszarach funkcjonalnych ośrodków metropolitalnych (miejskich);

- promowanie i wspieranie zarówno integracji w sieci powiąań ośrodków metropolitalnych (miejskich), jak i wzrostu konkurencyjności obszarów funkcjonalnych względem siebie;

- dokonywanie usprawnień w zakresie działań o charakterze prawnym i organizacyjnym, obejmujących dążenie do ujednolicenia i optymalizacji jakości usług publicznych oraz dostępu do nich obywateli, w szczególności usług wyższego rzędu, w obrębie takich obszarów, które pozwalają na ich integrację, mimo występujacych różnic z tytuły sposobu i form ich realizacji (usługi: komunalne, edukacyjne, administracyjne czy inwestycyjnych);

- wzmacnianie istoty funkcji wyższego rzędu (funkcji metropolitalnych: administracyjnej, nauki wyższej, transportowej, przemysłowej, kontrolno-decyzyjnej i turystycznej), wraz z podniesieniem rangi kooperacji podmiotów w obszarze partnerstwo otoczenia: publicznego, prywatnego i nauki;

- dążenie do rozwijania potencjału ośrodków do tworzenia innowacji (bazy dydaktyczne uczelni wyższych zgodne z kierunkami rozwoju regionu, regionalne ośrodki nauki, instytucje naukowo-badawcze o randze krajowej i międzynarodowej);

- wspieranie kompleksowych planów lokalizacji oraz rozwoju i efektywności działania instytucji wspomagających, a także koordynacja wszelkiej aktywności w otoczeniu (partnerzy podmiotów: publicznych, biznesu i naukowo-badawczych), dotyczących m.in. optymalizacji struktury rynku pracy, poprawy jakości i poszerzania oferty usług świadczonych przez publiczne i niepubliczne instytucje otoczenia biznesu, rozwoju kapitału ludzkiego i społecznego itd.

Obszary metropolitalne w latach 2014-2020, a nawet do 2030 r., będą stanowiły instytucjonalne narzędzie determinujące czynniki wpływające na rozwój społeczno-gospodarczy kraju, jako ośrodki o największym potencjale, a jednocześnie wystapią w roli podmiotu decydującego o sposobie zarządzania przestrzenia publiczną regionu, gdyż będą zajmowały istotną pozycję w układzie sieci powiązań ośrodków metropolitalnych w skali kraju i ujęciu międzynarodowym. Ważnym krokiem stanie się prawne usytuowanie obszarów metropolitalnych w organizacji struktury jednostek sektora finansów publicznych, obecnie bowiem prowadzą one działalność w postaci fakultatywnego podmiotu o różnorodnych funkcjach - są alternatywną formą aktywności względem zadań realizowanych przez jednostki samorządu terytorialnego (województwa, powiaty i gminy).

mgr Bartosz Edwarczyk

Uniwersytet Ekonomiczny w Poznaniu

bartosz.edwarczyk@ue.poznan.pl 


\section{DEVELOPMENT OF METROPOLITAN AREAS UNDER SELF-GOVERNMENT TRANSFORMATION IN POLAND 1990-2014}

\section{Summary}

The article presents the basic issues concerning the organisation and functioning of metropolitan areas in Poland within the last 25 years. The entire article is an attempt to determine the factors that have an impact on the metropolisation of large urban agglomerations and centres related to them spatially and institutionally located within the limits of their peripheral ring. First, the change in the system and the most important aspects that influence and result from social and business transformation after 1989 was presented. With regard to metropolitan areas, the basic outline of the process of metropolisation, the legal environment, the organisation and functioning, as well as the progressive increase in the importance of metropolities were described. Today's approach to the management of the network of environmentally interdependent and mutually cooperating sectors: public, private and non-profit, was also presented. The article also presents the conditions resulting from the country's development policy formulated within the framework of the basic strategic documents (long- and medium-term national development strategy, the concept of national spatial planning and the regional development strategy of the country), aimed at enabling further development and evaluation of metropolitan areas arising from the new European Union Financial Framework for 2014-2020. A general analysis of the metropolitan areas identified in Poland was also made, based on Polish statistics (GUS) using available data for the period 2010-2012. The author focuses on defining the most important provisions stemming from the previously enforced and the planned government policy of promoting the idea of the regional development of integrated activities involving local government units with particular emphasis on the role of metropolitan areas in providing services and delivering products of public utility. 
